\title{
Composition and Antioxidant Activity of Phenolic Compounds in Fruit of the Genus Rosa L.
}

\author{
Mindaugas Liaudanskas ${ }^{1,2, * \mathbb{D}}$, Irena Noreikienè ${ }^{3}$, Kristina Zymonè ${ }^{2}$, Rugilè Juodytė ${ }^{1}$, Vaidotas Žvikas ${ }^{2}$ \\ and Valdimaras Janulis ${ }^{1}(\mathbb{D}$ \\ 1 Department of Pharmacognosy, Lithuanian University of Health Sciences, Sukileliu av. 13, \\ LT-50162 Kaunas, Lithuania; farmakog2@lsmuni.lt (R.J.); valdimaras.janulis@lsmuni.lt (V.J.) \\ 2 Institute of Pharmaceutical Technologies, Lithuanian University of Health Sciences, Sukileliu av. 13, \\ LT-50162 Kaunas, Lithuania; kristina.zymone@lsmuni.lt (K.Z.); vaidotas.zvikas@lsmuni.lt (V.Ž.) \\ 3 Botanical Garden of Vilnius University, Kairènu str. 43, LT-10239 Vilnius, Lithuania; irena.noreikiene@bs.vu.lt \\ * Correspondence: mindaugas.liaudanskas@lsmuni.lt; Tel.: +370-683-48794; Fax: +370-37-220733
}

Citation: Liaudanskas, M.;

Noreikienė, I.; Zymonė, K.; Juodytė, R.; Žvikas, V.; Janulis, V. Composition and Antioxidant Activity of Phenolic Compounds in Fruit of the Genus Rosa L.. Antioxidants 2021, 10, 545. https://doi.org/10.3390/ antiox10040545

Academic Editor: Alfredo Aires

Received: 2 March 2021

Accepted: 29 March 2021

Published: 1 April 2021

Publisher's Note: MDPI stays neutral with regard to jurisdictional claims in published maps and institutional affiliations.

Copyright: (c) 2021 by the authors. Licensee MDPI, Basel, Switzerland. This article is an open access article distributed under the terms and conditions of the Creative Commons Attribution (CC BY) license (https:// creativecommons.org/licenses/by/ $4.0 /)$
Abstract: We investigated the qualitative and quantitative composition of phenolic compounds in the fruit of Rosa L. cultivars grown in Lithuania. The highest total content of phenolic compounds $(50.13 \pm 4.17 \mathrm{mg} \mathrm{GAE} / \mathrm{g}, p<0.05)$ was determined in fruit samples of Rosa pimpinellifolia L. cultivar "Single Cherry". The highest levels of hydroxycinnamic acid derivatives were determined in fruit samples of Rosa rugosa Thunb. cultivars "Dart's Defender" and "Adam Chodun". The highest flavonoid content was determined in fruit samples of Rosa multiflora Thunb. cultivar "Nana" and R. multiflora species. The strongest antioxidant activity evaluated by applying DPPH and FRAP assays was determined in fruit extracts of R. pimpinellifolia cultivar "Single Cherry" and R. rugosa cultivar "Adam Chodun". Qualitative and quantitative analysis of phenolic compounds in Rosa L. fruit was performed by applying UHPLC. The following phenolic compounds were identified in fruit samples: caffeic acid, chlorogenic acid, quercetin, quercitrin, (+)-catechin, (-)-epicatechin, (-)-epicatechin gallate, rutin, phloridzin, and kaempferol-3-O-glycoside. A strong correlation was determined between the total amount of phenolic compounds determined in extracts of the fruit samples of Rosa L. cultivars and the radical scavenging and reducing activity of their extracts in vitro $(R=0.767$ and 0.727 , respectively, $p<0.05)$.

Keywords: phenolic compounds; antioxidant activity; Rosa L. fruit; UHPLC-ESI-MS/MS analysis; UV-Vis spectrophotometry

\section{Introduction}

Rosaceae Juss. is a family of Angiospermae consisting of about 100 genera and 2830-3100 different plant species [1]. The genus Rosa L. includes about 200 species that grow in natural habitats and/or are cultivated [2,3]. Only eight naturally growing species are determined in Lithuania. Most commonly, botanical raw material of the fruit is collected from Rosa rugosa Thunb., Rosa majalis Herrm., and Rosa canina L. plants. Rosa L. is widespread throughout Europe, Asia, North America, and the Middle East [4].

The fruits of Rosa L. (Rosae pseudo-fructus) have long been used as raw material for making medicinal products [5]. The fruits have been determined to contain many different groups of biologically active compounds with a wide range of biological effects. This is the reason for the wide application of this raw material and its preparations in practical medicine and food industry of Lithuania and other countries of the world [6-8]. The fruits have been determined to have an anti-inflammatory $[9,10]$, antioxidant $[8,11]$, and antiproliferative [12] effects. Clinical studies have shown that the raw material of the fruit in dietary supplements reduces the symptoms of osteoarthritis [12-14]. R. canina fruit preparations protect the kidneys from oxidative stress [15] and have anti-inflammatory, antidiabetic, antimicrobial, and anticancer effects [6]. 
The fruit of Rosa L. is widely used in food preparation. In the past, this botanical raw material was used for the preparation of beverages, jellies, and jams. Studies are underway to replace some food additives partially or completely by using Rosa L. fruit [16]. Recently, the raw material of the fruit has been used in the production of probiotic beverages and yogurts, as well as an ingredient in soups $[17,18]$. A scientific study on the effect of purified R. pimpinellifolia fruit extract on yogurt quality was carried out [19].

It is important to investigate the variability of the qualitative and quantitative composition of raw medicinal plant materials that can be used as new botanical food additives. The results of research on the variability of phenolic compounds in Rosa L. fruit described in the scientific literature are fragmentary. So far, no studies on the quantitative and qualitative composition of phenolic compounds in the fruit of Rosa L. growing and cultivated in Lithuania have been performed.

It is important to study the effects of extracts of Rosa L. fruit samples in vitro, including the antioxidant effects of phenolic compounds, which have an impact on the prevention of various diseases. The relationship between food and health is becoming increasingly important as consumers want to eat healthy, tasty, and natural food grown in an organic environment, thus maintaining a healthy and balanced diet. The scientific literature describes the results of epidemiological and clinical studies that demonstrate the impact of diet on health. This has led researchers around the world to propose new functional foods that are not only a source of nutrients but are also important for the prevention of cancer, cardiovascular disorders, and diabetes; for strengthening of the immune system; and for slowing down the aging process [20-22].

A broad variety of analytical methods have been employed for the detection of phenolic compounds in raw medicinal plant materials and their products. Thin-layer and high-performance thin-layer chromatography; mass, infrared, and ultraviolet spectroscopy; and other analytical methods have been applied for the qualitative analysis of phenolics $[23,24]$. For the quantitative evaluation of phenolic compounds in plant matrices, HPLC and UV-Vis absorption spectrophotometry are the most widely used methods, while capillary zone electrophoresis is applied less frequently [25].

Spectrophotometry is often used for the evaluation of the total amount of phenolic compounds in samples of raw medicinal plant materials. One of the disadvantages of applying UV-Vis spectrophotometry is that it does not allow for determining the qualitative and quantitative composition of individual biologically active compounds-only the total amount of phenolic compounds or their individual groups (flavonoids, hydroxycinnamic acid derivatives, etc.) can be evaluated. Plant extracts are multicomponent matrices composed of biologically active compounds of different structures. To identify and quantify the composition of individual components of a plant extract, high-performance liquid chromatography is the method of choice, ensuring rapid, selective, and reproducible qualitative and quantitative analysis of phenolic compounds. Recently, ultrahigh-performance liquid chromatography (UHPLC) combined with mass spectrophotometry has been introduced for the analysis of biologically active compounds in biological matrices. Such a combination and use of these methods allows for a fast and effective qualitative and quantitative analysis of different groups of phenolic compounds.

The paper presents the results of the investigation on the variability of the quantitative and qualitative composition of phenolic compounds in fruit samples of the species of Rosa L. grown in Lithuania: Rosa rugosa Thunb., Rosa pimpinellifolia L., Rosa multiflora Thunb., and Rosa canina L. and their cultivars. We found no publications that focus on the composition of phenolic compounds and antioxidant activity of Rosa rugosa Thunb. (cultivars "Rudolf", "Dart's Defender", "Marie Bugnet", "Fru Dagmar Hastrup", and "Adam Chodun”), Rosa multiflora Thunb. (cultivar "Nana"), and Rosa pimpinellifolia L. (cultivars "Papula" and "Single Cherry"), except for Rosa rugosa Thunb. cultivar "Kornik", grown in Lithuanian climatic conditions. The obtained results of the study will also allow for using the fruit of other cultivated Rosa L. species and their cultivars for the preparation of raw medicinal 
plant materials and for expanding the range of botanical raw materials for the development of food additives, for use in the pharmaceutical and food industries, respectively [16].

\section{Materials and Methods}

\subsection{Plant Material}

The fruit samples of Rosa rugosa Thunb. (cultivars "Rudolf", "Dart's Defender", "Marie Bugnet", "Fru Dagmar Hastrup", "Kornik", and "Adam Chodun"), Rosa multiflora Thunb. (cultivar "Nana"), Rosa pimpinellifolia L. (cultivars "Papula" and "Single Cherry"), and Rosa canina L. were obtained from the collection of Vilnius University Botanical Garden $\left(54^{\circ} 40^{\prime} 56.762^{\prime \prime}, 25^{\circ} 14^{\prime} 52.832^{\prime \prime}\right.$ (World Geodetic System)).

\subsection{Chemicals}

The reagents used in the assays met all quality requirements and were of analytical grade. The following reagents were used in the study: ethanol $96 \%(v / v)$ (manufactured by SC Vilniaus degtinè, Vilnius, Lithuania), Folin-Ciocalteu reagent, gallic acid monohydrate, ferric chloride hexahydrate $\left(\mathrm{FeCl}_{3} \times 6 \mathrm{H}_{2} \mathrm{O}\right)$, sodium acetate trihydrate $\left(\mathrm{CH}_{3} \mathrm{COONa} \times 3 \mathrm{H}_{2} \mathrm{O}\right)$, DPPH (2,2-diphenyl-1-picrylhydrazyl), Trolox $(( \pm)$-6-hydroxy2,5,7,8-tetramethylchromano-2-carboxylic acid), hexamethylenetetramine, chlorogenic acid, caffeic acid, phloridzin, quercetin, quercitrin, kaempferol-3-O-glycoside (+)-catechin, $(-)$ epicatechin, and (-)-epicatechin gallate (Sigma-Aldrich, Steinheim, Germany), sodium carbonate $\left(\mathrm{Na}_{2} \mathrm{CO}_{3}\right)$, rutin (Carl Roth $\mathrm{GmbH}$, Karlsruhe, Germany), glacial acetic acid 99.8\% (Lachner, Neratovice, Czech Republic), 2,4,6-tripyridyl-s-triazine (TPTZ) (Alfa Aesar, Karlsruhe, Germany), concentrated hydrochloric acid, aluminum chloride hexahydrate (Fluka-Chemie, Buchs, Switzerland), sodium molybdate, sodium nitrite, and sodium hydroxide (Chempur, Tarnowskie Gory, Poland). Purified water was prepared, using the Milli- $Q^{\circledR}$ water-purification system (Millipore Co., Bedford, MA, USA).

\subsection{Preparation of Rosa L. Fruit Samples}

The Rosa L. fruits were dried in a well-ventilated and dry room. The dried Rosa L. fruit samples were ground with an Retsch GM 200 electric grinder. The ground raw material was stored in a dark and dry place, in tightly closed containers. The loss upon the drying of the raw material was determined by applying the technique described in the European Pharmacopoeia 07/2019:20232 [26].

\subsection{Preparation of Rosa L. Fruit Extracts}

During the study, $0.5 \mathrm{~g}$ (exact weight, weighed on a Sartorius CP64-0CE analytical balance (Sartorius AG, Gottingen, Germany)) of dried Rosa L. fruit powder was used, adding $10 \mathrm{~mL}$ of $40 \%(\mathrm{v} / \mathrm{v})$ ethanol, and extracting in an ultrasonic bath Bandelin Sonorex Digital $10 \mathrm{P}$ (Sigma-Aldrich, Darmstadt, Germany), for $50 \mathrm{~min}$, at a temperature of $25^{\circ} \mathrm{C}$, at a frequency of $80 \mathrm{kHz}$, and at a power level of $1130 \mathrm{~W}$. The obtained extract was filtered, and the dried Rosa L. fruit-powder mass remaining on the filter was washed with $40 \%$ $(v / v)$ ethanol. The filtered extract was poured into $10 \mathrm{~mL}$ measuring flasks, adding $40 \%$ $(v / v)$ ethanol up to the marking. Prior to the UHPLC analysis, the extracts were filtered through Carl Roth membrane filters (Carl Roth GmbH \& Co. KG, Karlsruhe, Germany) with $0.22 \mu \mathrm{m}$ pore size.

\subsection{Spectrophotometric Assays}

2.5.1. Determination of the Total Amounts of Phenolic Compounds, Flavonoids, and Hydroxycinnamic Acid Derivatives

All spectrophotometric studies were performed on a UV-visible light (UV-Vis) spectrophotometer M550 (Spectronic CamSpec, Garforth, UK). The total phenolic content in the ethanol extracts of Rosa L. fruit was determined by using the Folin-Ciocalteu method [27], calculated from a gallic acid calibration curve, and expressed as mg gallic acid equivalent (GAE) per one gram of absolutely dry weight (DW) (mg GAE/g DW). The total amount of 
flavonoids in the ethanol extracts of Rosa L. fruit was determined by using the described methodology [28], calculated from a rutin calibration curve, and expressed as mg rutin equivalent (RE) per one gram of absolutely dry weight (DW) (mg RE/g DW). The total amount hydroxycinnamic acid derivatives in the ethanol extracts of Rosa L. fruit was determined by using the described methodology [29], calculated from a chlorogenic acid calibration curve, and expressed as mg chlorogenic acid equivalent (CAE) per one gram of absolutely dry weight (DW) (mg CAE/g DW).

\subsubsection{Evaluation of Antioxidant Activity}

Calculation of Antioxidant Activity of the Ethanol Extract of Rosa L. Fruit. The antioxidant activity of the extracts was calculated from the Trolox calibration curve and was expressed as $\mu \mathrm{mol}$ of the Trolox equivalent (TE) per one gram of absolutely dry weight (DW).

DPPH ${ }^{\bullet}$ Free Radical Scavenging Assay. The DPPH ${ }^{\bullet}$ free radical scavenging activity was determined, using the method proposed by Brand-Williams et al. [30]. DPPH ${ }^{\bullet}$ solution in $96.3 \% v / v$ ethanol $\left(3 \mathrm{~mL}, 6 \times 10^{-5} \mathrm{M}\right)$ was mixed with $10 \mu \mathrm{L}$ of the ethanol extract of Rosa $\mathrm{L}$. fruit. A decrease in absorbance was determined at a wavelength of $515 \mathrm{~nm}$ after keeping the samples for $30 \mathrm{~min}$ in the dark.

FRAP Assay. FRAP solution included TPTZ $(0.01 \mathrm{M}$ dissolved in $0.04 \mathrm{M} \mathrm{HCl})$, $\mathrm{FeCl}_{3} \times 6 \mathrm{H}_{2} \mathrm{O}(0.02 \mathrm{M}$ in water), and acetate buffer (0.3 M, pH 3.6) (ratio 1:1:10). During the evaluation, $3 \mathrm{~mL}$ of a freshly prepared FRAP reagent was mixed with $10 \mu \mathrm{L}$ of the extracts. An increase in absorbance was recorded at $\lambda=593 \mathrm{~nm}$ [31].

\subsection{Chromatographic Assay}

The variability of the qualitative and quantitative composition and content of phenolic compounds in Rosa L. fruit samples was evaluated, using ultrahigh-performance liquid chromatography-mass spectrometry, by applying the technique described and validated by Gonzalez-Burgos et al. [32]. Separation of phenolic compounds was performed with Acquity H-class UPLC system (Waters, Milford, MA, USA) equipped with Xevo triple quadrupole tandem mass spectrometer (Waters, Milford, MA, USA) with an electrospray ionization source (ESI), to obtain MS/MS data. YMC Triart C18 $(100 \times 2.0 \mathrm{~mm} ; 1.9 \mu \mathrm{m})$ column (YMC Europe Gmbh, Dislanken, Germany) was used for analysis. Column temperature was maintained at $40{ }^{\circ} \mathrm{C}$. Gradient elution was performed with mobile phase consisting of $0.1 \%$ formic acid water solution (solvent A) and acetonitrile (solvent B) with flow rate set to $0.5 \mathrm{~mL} \mathrm{~min}^{-1}$. Linear gradient profile was applied as follows for solvent $\mathrm{A}$ : initially $95 \%$ for $1 \mathrm{~min}$, to $70 \%$ over $4 \mathrm{~min}, 50 \%$ over $7 \mathrm{~min}$, and $95 \%$ over $2 \mathrm{~min}$. Negative electrospray ionization was applied for analysis: capillary voltage, $-2 \mathrm{kV}$; source temperature, $150{ }^{\circ} \mathrm{C}$; desolvation temperature, $400{ }^{\circ} \mathrm{C}$; desolvation gas flow, $700 \mathrm{~L} \mathrm{~h}^{-1}$; and cone gas flow, $20 \mathrm{~L} \mathrm{~h}^{-1}$. Collision energy and cone voltage were optimized for each compound separately. Mass spectrometry parameters for the analysis of phenolic compounds are presented in Table 1.

\subsection{Statistical Analysis}

Data analysis was carried out, using computer software Microsoft Excel 2016 (Microsoft Corp., Redmond, WA, USA) and SPSS Statistics 20 (IBM, Armonk, NY, USA). During the analysis, we calculated arithmetic means and standard deviations of three repeated measurements. A univariate dispersion analysis model (ANOVA) was applied for determining whether the differences between the compared data were statistically significant. Differences between the samples were determined by applying Tukey's multiple comparison test. The correlation was evaluated by Pearson's analysis. Differences at $p<0.05$ were considered to be statistically significant. According to the quantitative composition of identified compounds, the tested samples were compared by the method of hierarchical cluster analysis, using squared Euclidean distances. Principal component analysis was performed, taking into account factors with eigenvalues higher than 1. 
Table 1. Mass spectrometry parameters for the analysis of phenolic compounds.

\begin{tabular}{ccccc}
\hline Compound & Parent Ion $(\mathbf{m} / \mathbf{z})$ & Daughter Ion $(\mathbf{m} / \mathbf{z})$ & Cone Voltage, V & Collision Energy, eV \\
\hline Caffeic acid & 179 & 107 & 36 & 22 \\
\hline (-)-Epicatechin & 289 & 123 & 60 & 34 \\
\hline (+)-Catechin & 289 & 123 & 60 & 20 \\
\hline Quercetin & 301 & 151 & 48 & 14 \\
\hline Chlorogenic acid & 353 & 191 & 32 & 14 \\
\hline Phloridzin & 435 & 273 & 42 & 16 \\
\hline (-)-Epicatechin gallate & 441 & 169 & 40 & 28 \\
\hline Quempferol-3-glucoside & 447 & 284 & 54 & 26 \\
\hline Rutin & 447 & 300 & 50 & 70 \\
\hline
\end{tabular}

\section{Results and Discussion}

3.1. Determination of the Total Content of Phenolic Compounds, Flavonoids, and Hydroxycinnamic Acid Derivatives in Rosa L. Fruit Samples

Spectrophotometry is often used to assess the quality of raw medicinal plant materials and preparations made from them. The results obtained by applying this technique allow for determining the quantitative composition of groups of biologically active compounds. To evaluate the variability of phenolic compounds, flavonoids, and hydroxycinnamic acid derivatives in fruit samples of different Rosa L. species and cultivars, we selected the methodologies used for studies of raw medicinal plant materials.

The total amount of phenolic compounds in Rosa L. fruit samples was determined to vary from $14.99 \pm 0.68 \mathrm{mg} \mathrm{GAE} / \mathrm{g}$ to $50.13 \pm 4.17 \mathrm{mg} \mathrm{GAE} / \mathrm{g}$ (Figure 1). The mean total phenolic content in Rosa L. fruit samples was estimated to be $28.03 \pm 2.05 \mathrm{mg} \mathrm{GAE} / \mathrm{g}$. The highest amount of phenolic compounds $(50.13 \pm 4.17 \mathrm{mg} \mathrm{GAE} / \mathrm{g}, p<0.05)$ was determined in fruit samples of $R$. pimpinellifolia cultivar "Single Cherry". The lowest content of phenolic compounds was determined in fruit samples of $R$. multiflora (14.99 $\pm 0.68 \mathrm{mg} \mathrm{GAE} / \mathrm{g}$ ) and in samples of R. multiflora cultivar "Nana" (21.09 $\pm 1.31 \mathrm{mg} \mathrm{GAE} / \mathrm{g})$, as well as in fruit samples of $R$. rugosa cultivar "Fru Dagmar Hastrup" (21.57 $\pm 0.02 \mathrm{mg}$ GAE/g) and in fruit samples of $R$. canina (21.61 $\pm 0.6 \mathrm{mg} \mathrm{GAE} / \mathrm{g}$ ) (Figure 1). There was no statistically significant difference in the quantitative composition of phenolic compounds between fruit samples of different Rosa L. species and cultivars $(p>0.05)$.

Demir et al. investigated the qualitative and quantitative composition of fruit samples of different species of Ros $a$ L. [23]. The total amount of phenolic compounds determined in the samples studied by these scientists ranged from 31.08 to $52.94 \mathrm{mg}$ GAE/g DW) [18]. Nađpal et al. analyzed fruit samples of $R$. canina and Rosa arvensis Huds. The total amount of the detected phenolic compounds ranged from 6.63 to $96.2 \mathrm{mg}$ GAE/g DW [7].

Yang et al. investigated fruit samples of Rosa roxburghii Tratt. grown in China. Total content of phenolic compounds (173 mg GAE/g DW) in fruit samples of this species was significantly higher than contents which were determined in our study [33]. Such results may have been due to the different climatic conditions and interspecific differences between studied Rosa L. fruit samples.

The spectrophotometrically determined variability of the amount of hydroxycinnamic acid derivatives was from $4.22 \pm 0.31 \mathrm{mg} \mathrm{CAE} / \mathrm{g}$ to $11.76 \pm 0.12 \mathrm{mg} \mathrm{CAE} / \mathrm{g}$ (Figure 2). The mean total amount of hydroxycinnamic acid derivatives in Rosa L. fruit samples was determined to be $7.01 \pm 0.49 \mathrm{mg} \mathrm{CAE} / \mathrm{g}$. The highest levels of hydroxycinnamic acid derivatives were determined in fruit samples of $R$. rugosa cultivar "Dart's Defender" (11.76 $\pm 0.12 \mathrm{mg}$ CAE/g) and R. rugosa cultivar "Adam Chodun" (9.68 $\pm 1.96 \mathrm{mg} \mathrm{CAE} / \mathrm{g})$. The lowest levels of hydroxycinnamic acid derivatives were determined in fruit samples of $R$. pimpinellifolia cultivar "Single Cherry" (4.22 $\pm 0.31 \mathrm{mg} \mathrm{CAE} / \mathrm{g})$, R. multiflora (5.04 $\pm 0.03 \mathrm{mg} \mathrm{CAE} / \mathrm{g})$, 
R. rugosa cultivar "Marie Bugnet" (5.26 $\pm 0.13 \mathrm{mg}$ CAE/g), and R. rugosa cultivar "Kornik" $(5.34 \pm 0.14 \mathrm{mg} \mathrm{CAE} / \mathrm{g})$.

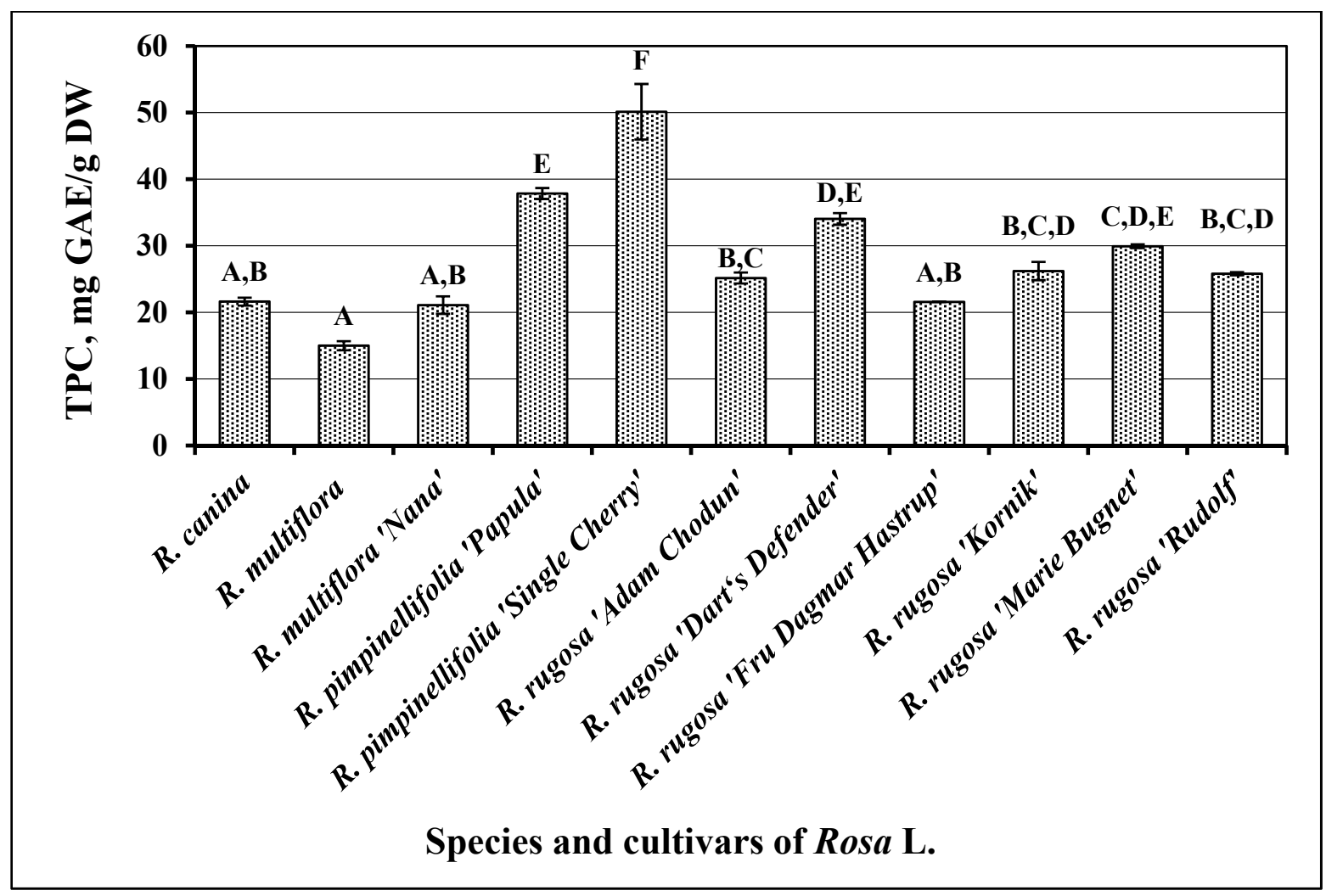

Figure 1. Variability of the total content of phenolic compounds in Rosa L. fruit samples; different letters indicate statistically significant $(p<0.05)$ differences between the samples.

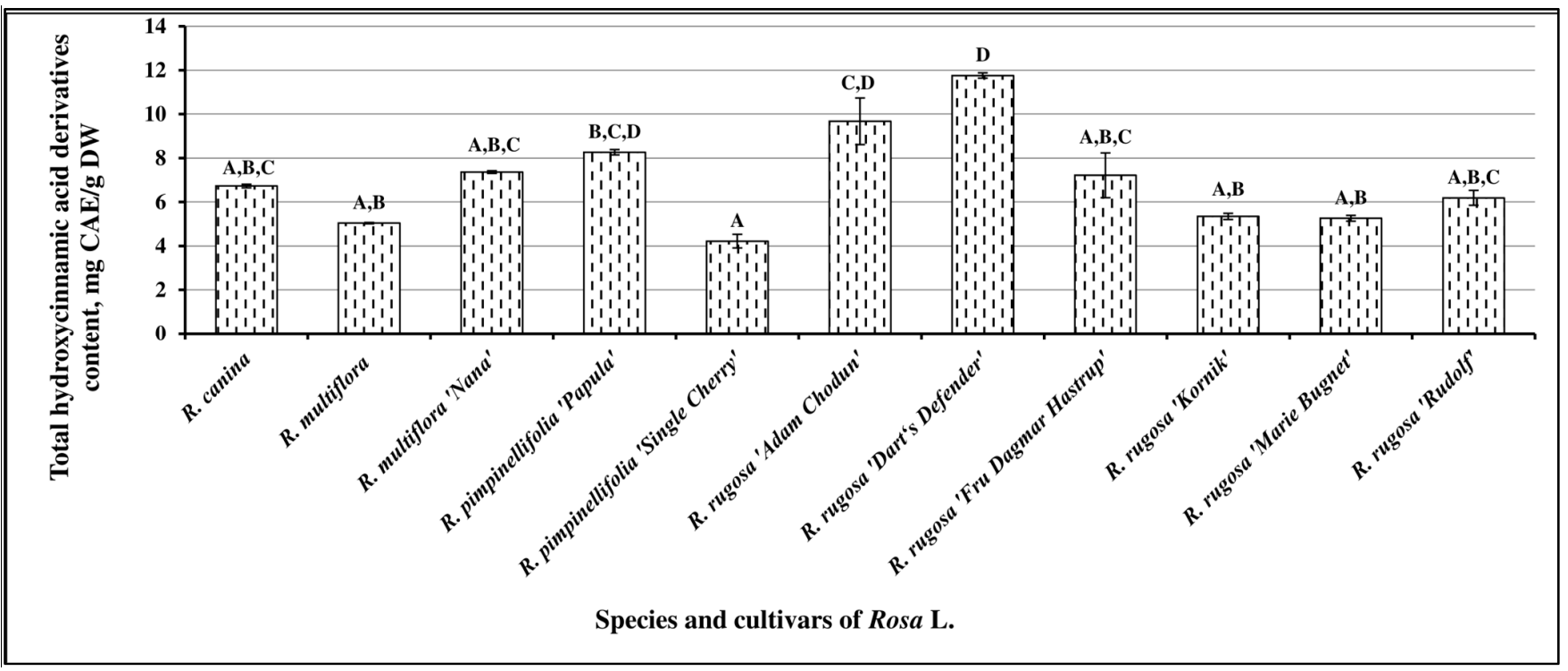

Figure 2. Variability of the total content of hydroxycinnamic acid derivatives in Rosa L. fruit samples; different letters indicate statistically significant $(p<0.05)$ differences between the samples.

Spectrophotometry showed that th total amount of flavonoids in the samples of different Rosa L. species and cultivars varied from $0.55 \pm 0.03 \mathrm{mg} \mathrm{RE} / \mathrm{g}$ to $5.01 \pm 0.01 \mathrm{mg}$ RE/g. The mean amount of flavonoids determined in Rosa L. fruit samples was $2.84 \pm 0.27 \mathrm{mg}$ 
$\mathrm{RE} / \mathrm{g}$. The highest total amount of flavonoids was determined in fruit samples of R. multiflora cultivar "Nana" (5.01 $\pm 0.01 \mathrm{mg}$ RE/g) and R. multiflora (4.80 $\pm 0.06 \mathrm{mg} \mathrm{RE} / \mathrm{g})$. The lowest total amount of flavonoids $(0.55 \pm 0.03 \mathrm{mg} \mathrm{RE} / \mathrm{g}, p<0.05)$ was determined in fruit samples of R. pimpinellifolia cultivar "Single Cherry" (Figure 3). Nađpal et al. investigated the variability of the total flavonoid content in fruit samples of $R$. canina and Rosa arvensis Huds. Their total flavonoid content ranged from 0.63 to $1.48 \mathrm{mg} \mathrm{RE} / \mathrm{g}$ [34]. Tahirovic et al. (2017) evaluated the total flavonoid content in fruit samples of $R$. canina and determined it to vary from 0.214 to $0.675 \mathrm{mg} \mathrm{RE} / \mathrm{g}$ [35]. The comparison of the data of these studies with the results obtained in our study showed that fruit samples of Rosa L. grown in Lithuania had higher total amounts of flavonoids.

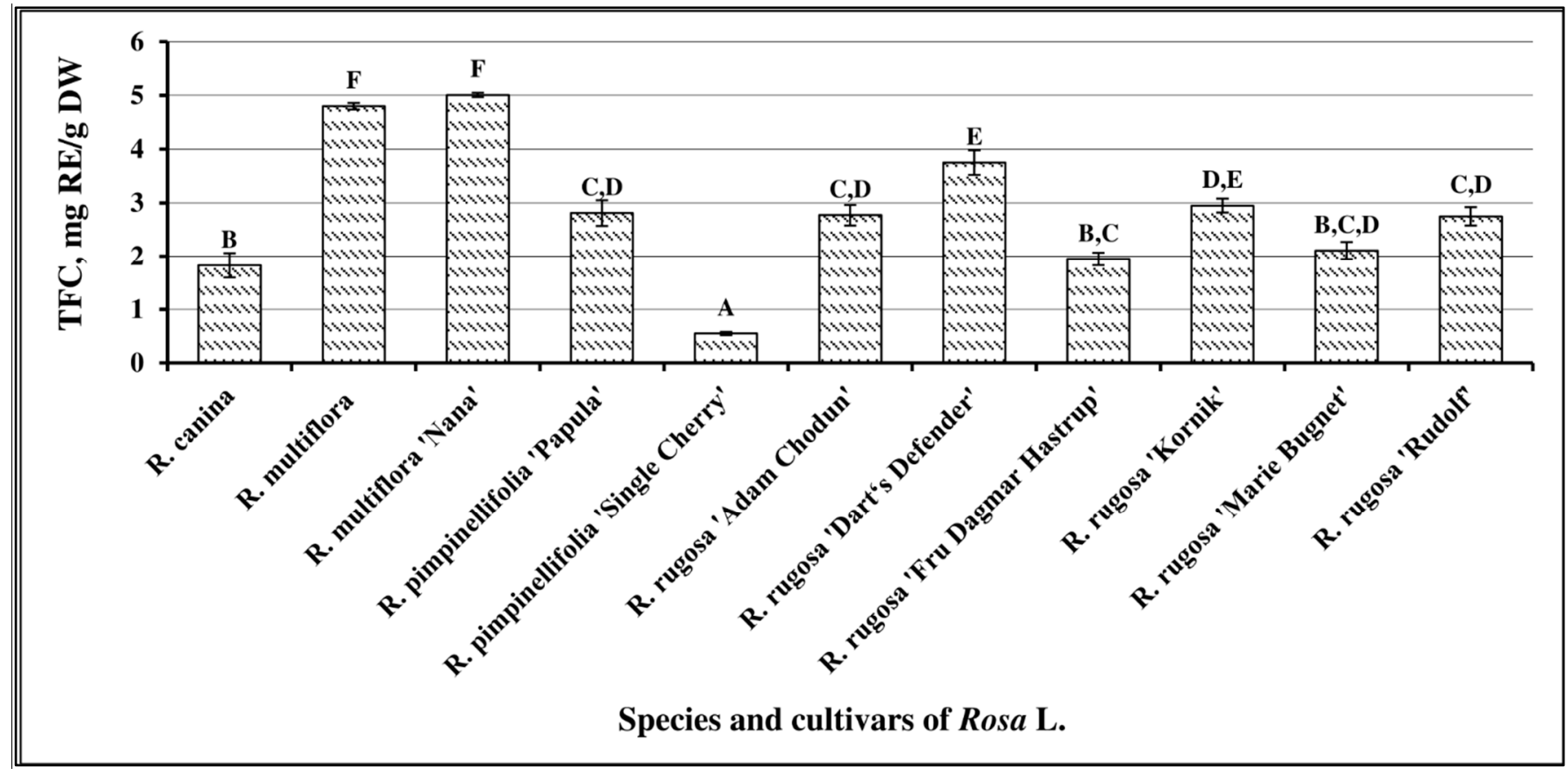

Figure 3. Variability of the total content of flavonoids in Rosa L. fruit samples; different letters indicate statistically significant $(p<0.05)$ differences between the samples.

The data on the patterns of variability in the total phenolic and flavonoid content in Rosa L. fruit are scarce. Therefore, this study provides new knowledge about total phenolic and flavonoid content in Rosa L. fruit of the cultivars grown under Lithuanian climatic conditions; it also allows for the comparison of the obtained results with those of other studies and is valuable for carrying out a search for promising raw medicinal plant materials that accumulate biologically active substances.

\subsection{Determination of the Qualitative and Quantitative Composition of Phenolic Compounds by UHPLC in Rosa L. Fruit Samples}

In our study, we used UHPLC to analyze Rosa L. fruit samples. In the analyzed fruit samples, we identified phenolic acids (caffeic acid and chlorogenic acid) and flavonoids (quercetin, quercitrin, (+)-catechin, (-)-epicatechin, (-)-epicatechin gallate, rutin, phloridzin, and kaempferol-3-O-glucoside). The qualitative composition of phenolic compounds in the fruit extract of $R$. multiflora cultivar "Nana" determined via UHPLC is presented in the UHPLC chromatogram (Figure 4). 


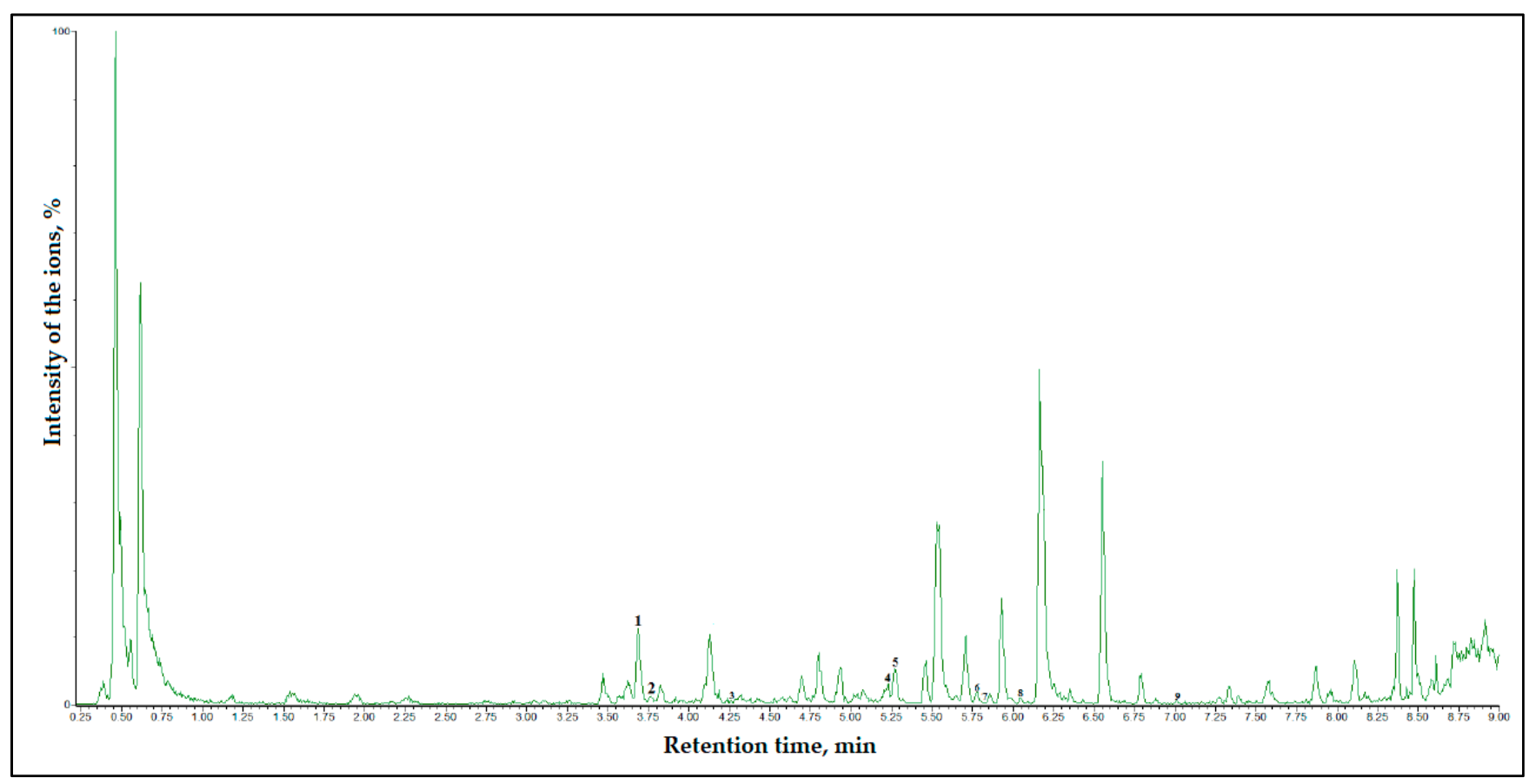

Figure 4. UHPLC chromatogram of fruit extract of $R$. multiflora (cultivar "Nana"). The numbers indicate the compounds identified: 1-(+)-catechin, 2-chlorogenic acid, 3-(-)-epicatechin, 4-rutin, 5-(-)-epicatechin gallate, 6-kaempferol-3O-glucoside, 7-quercitrin, 8-phloridzin, and 9-quercetin.

Qualitative analysis via UHPLC showed that the studied Rosa L. fruit samples contained phenolic acids-caffeic acid and chlorogenic acid. No phenolic acids were detected in fruit samples of R. rugosa cultivar "Adam Chodun" and R. multiflora (Table 2). Phenolic acids are often determined in organs of Angiospermae, they can act as co-compounds, and often have biological effects, determining the effects of medicinal preparations [36,37]. Phenolic acids have strong antioxidant [38], anti-inflammatory [39], renoprotective [40,41], hepatoprotective [42], and anti-diabetic [38,43] properties.

Table 2. Variability of the quantitative composition of phenolic acids and flavan-3-ols in Rosa L. fruit samples

\begin{tabular}{|c|c|c|c|c|c|}
\hline Compound, $\mu \mathrm{g} / \mathrm{g}$ DW & Caffeic Acid & Chlorogenic Acid & $(+)$-Catechin & (-)-Epicatechin & (-)-Epicatechin Gallate \\
\hline R. canina & ND & $2.68 \pm 0.03^{b}$ & $107.93 \pm 1.93^{\mathrm{e}}$ & ND & $117.52 \pm 2.27^{b, c}$ \\
\hline R. multiflora & ND & ND & $145.37 \pm 3.38^{d}$ & ND & $84.32 \pm 0.76^{\mathrm{d}}$ \\
\hline R. multiflora "Nana" & ND & $16.31 \pm 0.85^{\mathrm{a}}$ & $592.63 \pm 6.39^{a}$ & $2.74 \pm 0.07^{b}$ & $126.15 \pm 1.70^{b}$ \\
\hline R. pimpinellifolia "Papula" & $4.81 \pm 0.02^{b}$ & $1.62 \pm 0.08^{b, c}$ & $89.17 \pm 1.25^{f}$ & $9.71 \pm 0.04^{\mathrm{a}}$ & $149.29 \pm 2.76^{a}$ \\
\hline R. pimpinellifolia "Single Cherry" & $3.73 \pm 0.03^{c, d}$ & ND & $39.43 \pm 0.93^{g}$ & $0.38 \pm 0.02^{\mathrm{e}}$ & ND \\
\hline R. rugosa "Adam Chodun" & ND & ND & $93.73 \pm 1.83^{\mathrm{e}, \mathrm{f}}$ & $1.99 \pm 0.04$ & $85.89 \pm 1.53^{d}$ \\
\hline R. rugosa “Dart's Defender" & $3.69 \pm 0.07^{\mathrm{c}, \mathrm{d}}$ & $0.29 \pm 0.01^{c}$ & $232.08 \pm 3.92^{b}$ & $0.02 \pm 0.001^{\mathrm{f}}$ & $122.67 \pm 3.41^{b, c}$ \\
\hline R. rugosa "Fru Dagmar Hastrup" & $3.46 \pm 0.06^{\mathrm{d}}$ & ND & $43.66 \pm 0.86^{g}$ & $0.90 \pm 0.05^{\mathrm{d}}$ & ND \\
\hline R. rugosa "Kornik" & $3.95 \pm 0.10^{c}$ & $\mathrm{ND}$ & $50.38 \pm 0.65^{g}$ & ND & $113.01 \pm 2.42^{c}$ \\
\hline R. rugosa "Marie Bugnet" & ND & $0.87 \pm 0.01^{b, c}$ & $197.96 \pm 3.47^{c}$ & $0.22 \pm 0.01^{\mathrm{e}, \mathrm{f}}$ & $79.61 \pm 0.83^{d}$ \\
\hline R. rugosa "Rudolf" & $5.78 \pm 0.07^{\mathrm{a}}$ & ND & $52.10 \pm 0.99 \mathrm{~g}$ & ND & ND \\
\hline
\end{tabular}

DW, dry weight; different letters indicate statistically significant differences in the amounts of individual compounds of these groups in Rosa L. fruit samples $(p<0.05)$. ND-Not detected.

Using UHPLC, we analyzed the quantitative composition of the phenolic acids. The highest amount of caffeic acid $(5.78 \pm 0.07 \mu \mathrm{g} / \mathrm{g}, p<0.05)$ was determined in fruit samples of $R$. rugosa cultivar "Rudolf". The lowest amount of caffeic acid was detected in 
in fruit samples of $R$. rugosa cultivar "Fru Dagmar Hastrup" (3.46 $\pm 0.06 \mu \mathrm{g} / \mathrm{g})$, R. rugosa cultivar "Dart's Defender" (3.69 $\pm 0.07 \mu \mathrm{g} / \mathrm{g})$, and R. pimpinellifolia cultivar "Single Cherry" (3.73 $\pm 0.03 \mu \mathrm{g} / \mathrm{g}$ ) (Table 2). No caffeic acid was detected in fruit samples of $R$. rugosa cultivars "Adam Chodun" or "Marie Bugnet", R. canina, R. multiflora, or R. multiflora cultivar "Nana". The highest amount of chlorogenic acid $(16.31 \pm 0.85 \mu \mathrm{g} / \mathrm{g}, p<0.05)$ was determined in fruit samples of $R$. multiflora cultivar "Nana". The lowest amount of chlorogenic acid was detected in fruit samples of R. rugosa cultivars "Dart's Defender" $(0.29 \pm 0.01 \mu \mathrm{g} / \mathrm{g})$ and "Marie Bugnet" $(0.87 \pm 0.01 \mu \mathrm{g} / \mathrm{g})$ and $R$. pimpinellifolia cultivar "Papula" (1.62 $\pm 0.08 \mu \mathrm{g} / \mathrm{g})$. No chlorogenic acid was detected in fruit samples of R. rugosa (cultivars "Adam Chodun", "Kornik", “Rudolf", and "Fru Dagmar Hastrup"), R. pimpinellifolia cultivar "Single Cherry", or R. multiflora.

The following compounds of the flavan-3-ol group were detected by using ultrahighperformance liquid chromatography in Rosa L. fruit samples: (+)-catechin, (-)-epicatechin, and (-)-epicatechin gallate (Table 2). Flavan-3-ols are important for the human body as they exhibit antioxidant [44,45], anticancer [46], anti-inflammatory [47], platelet aggregationmodulating [48], and cholesterol-reducing [49,50] effects.

$(+)$-Catechin was identified in Rosa L. fruit samples of all the studied cultivars. Its content in Rosa L. fruit samples varied from 39.43 to $592.63 \mu \mathrm{g} / \mathrm{g}$. The highest amount of (+)catechin was determined in fruit samples of R. multiflora cultivar "Nana" $(592.63 \pm 6.39 \mu \mathrm{g} / \mathrm{g}$, $p<0.05$ ), and the lowest amount was determined in fruit samples of $R$. pimpinellifolia cultivar "Single Cherry" (39.43 $\pm 0.93 \mu \mathrm{g} / \mathrm{g}$ ) and R. rugosa cultivars "Fru Dagmar Hastrup" $(43.66 \pm 0.86 \mu \mathrm{g} / \mathrm{g})$, "Kornik" (50.38 $\pm 0.65 \mu \mathrm{g} / \mathrm{g})$, and "Rudolf" $(52.1 \pm 0.99 \mu \mathrm{g} / \mathrm{g})$. The highest amount of $(-)$-epicatechin $(9.71 \pm 0.04 \mu \mathrm{g} / \mathrm{g}, p<0.05)$ was determined in fruit samples of R. pimpinellifolia cultivar "Papula", and the lowest amount $(0.02 \pm 0.01 \mu \mathrm{g} / \mathrm{g})$ $p<0.05$ ) - in fruit samples of R. rugosa cultivar "Dart's Defender" (Table 2). The amount of (-)-epicatechin gallate in Rosa L. fruit samples ranged from 79.6 to $149.29 \mu \mathrm{g} / \mathrm{g}$. The highest amount of $(-)$-epicatechin gallate $(149.29 \pm 2.76 \mu \mathrm{g} / \mathrm{g}, p<0.05)$ was determined in fruit samples of R. pimpinellifolia cultivar "Papula", and the lowest amount-in fruit samples of R. rugosa cultivar "Marie Bugnet" (79.61 $\pm 0.83 \mu \mathrm{g} / \mathrm{g})$, R. multiflora $(84.32 \pm 0.76 \mu \mathrm{g} / \mathrm{g})$, and R. rugosa cultivar "Adam Chodun" (85.89 $\pm 1.53 \mu \mathrm{g} / \mathrm{g})$. No (-)-epicatechin gallate was detected in fruit samples of R. pimpinellifolia cultivar "Single Cherry" or in R. rugosa cultivars "Rudolf" or "Fru Dagmar Hastrup" (Table 2).

Demir et al. studied the variability of the composition of phenolic compounds in the fruit of different species of Rosa L. In their studied fruit samples of Rosa L., (+)-catechin content ranged from 7.18 to $50.46 \mu \mathrm{g} / \mathrm{g}$. Most of the Rosa L. fruit samples evaluated in our study contained higher amounts of this compound. Chlorogenic acid and (+)-catechin were identified in R. canina fruit samples grown in Poland [51]. (+)-Catechin and other compounds of flavan-3-ols group were identified in R. canina fruit samples, collected in Algeria [52]. Korean researchers identified chlorogenic and caffeic acids in fruit samples of $R$. multiflora [53]. Nađpal et al. examined fruit samples of $R$. canina and $R$. arvensis species. The $(+)$-catechin content $(2.37-7.83 \mu \mathrm{g} / \mathrm{g})$ reported by these researchers was significantly lower than the levels of this compound determined in our Rosa L. fruit samples, while the amount of (-)-epicatechin $(1.72-4.74 \mu \mathrm{g} / \mathrm{g})$ was close to the levels determined in our study. Demir et al. detected (-)-epicatechin gallate only in the fruit sample of $R$. dumalis subsp. Boissieri, and its content was lower than the amounts of this compound determined in the fruit samples of the cultivars evaluated in our study. The amounts of chlorogenic and caffeic acids determined by these scientists in their studied samples of various species of Rosa L. were higher than those determined in Rosa L. fruit samples evaluated in our study [18]. Such qualitative and quantitative differences in fruit composition may have been due to differences in Rosa L. species, different climatic conditions, soil composition, and other factors.

In the investigated extracts of Rosa L. fruit samples, flavonols were the most abundant group of phenolic compounds. These compounds are important for human health because of their strong antioxidant and anticancer activities [54-56]. The consumption of 
products rich in quercetin and its glycosides reduces the risk of cardiovascular $[57,58]$ and neurodegenerative diseases [59,60].

Quantitative analysis of kaempferol-3-O-glucoside by ultrahigh performance liquid chromatography showed that fruit samples of $R$. multiflora cultivar "Nana" contained the highest amount of kaempferol-3-O-glucoside $(46.47 \pm 1.38 \mu \mathrm{g} / \mathrm{g}, p<0.05)$, while the lowest amount of this compound was determined in fruit samples of $R$. canina $(3.34 \pm 0.51 \mu \mathrm{g} / \mathrm{g})$ and $R$. rugosa variety "Rudolf" $(0.68 \pm 0.01 \mu \mathrm{g} / \mathrm{g})$. The amounts of kaempferol-3-Oglucoside reported by Nađpal et al. $(1.77 \mu \mathrm{g} / \mathrm{g}$ and $3.04 \mu \mathrm{g} / \mathrm{g})$ were lower than the amounts of this compound determined in most of the Rosa L. fruit samples tested in our study [7]. The highest amount of phloridzin $(28.75 \pm 1.25 \mu \mathrm{g} / \mathrm{g}, p<0.05)$ was determined in fruit samples of $R$. multiflora cultivar "Nana", while the lowest amount of this compound was determined in fruit samples of $R$. rugosa cultivar "Rudolf" $(1.51 \pm 0.01 \mu \mathrm{g} / \mathrm{g})$, R. pimpinellifolia cultivar "Papula" (3.99 $\pm 0.27 \mu \mathrm{g} / \mathrm{g}$ ), and R. rugosa cultivar "Kornik" $(5.73 \pm 0.21 \mu \mathrm{g} / \mathrm{g})$. The highest amount of quercetin $(43.96 \pm 0.12 \mu \mathrm{g} / \mathrm{g}, p<0.05)$ was determined in fruit samples of $R$. pimpinellifolia cultivar "Single Cherry". The lowest amounts of quercetin were determined in fruit samples of R. multiflora $(5.56 \pm 0.32 \mu \mathrm{g} / \mathrm{g})$, R. pimpinellifolia cultivar "Papula" $(6.73 \pm 0.32 \mu \mathrm{g} / \mathrm{g})$, and R. multiflora cultivar "Nana" $(6.95 \pm 0.06 \mu \mathrm{g} / \mathrm{g})$. Quercitrin was identified in all Rosa L. fruit samples, its mean amount being $44.62 \pm 18.32 \mu \mathrm{g} / \mathrm{g}$. The highest amount of quercitrin $(278.47 \pm 2.65 \mu \mathrm{g} / \mathrm{g}, p<0.05)$ was determined in fruit samples of R. multiflora cultivar "Nana", and the lowest amount was determined in R. rugosa cultivars "Rudolf" $(0.52 \pm 0.42 \mu \mathrm{g} / \mathrm{g})$ and "Adam Chodun" $(1.75 \pm 0.04 \mu \mathrm{g} / \mathrm{g})$, R. pimpinellifolia $\mathrm{L}$. cultivars "Single Cherry" $(1.83 \pm 0.04 \mu \mathrm{g} / \mathrm{g})$ and "Papula" (2.52 $\pm 0.39 \mu \mathrm{g} / \mathrm{g})$, R. canina $(2.63 \pm 0.01 \mu \mathrm{g} / \mathrm{g})$, and $R$. rugosa cultivars "Fru Dagmar Hastrup" $(2.79 \pm 0.13 \mu \mathrm{g} / \mathrm{g})$ and "Kornik" $(3.83 \pm 0.12 \mu \mathrm{g} / \mathrm{g})$. The amount of quercitrin determined by Nađpal et al. varied from 27.1 to $113.0 \mu \mathrm{g} / \mathrm{g}$ [7]. The highest amount of rutin $(19.44 \pm 1.41 \mu \mathrm{g} / \mathrm{g}, p<0.05)$ was determined in fruit samples of $R$. multiflora cultivar "Nana", and the lowest amount was determined in R. rugosa cultivars "Kornik" $(0.87 \pm 0.11 \mu \mathrm{g} / \mathrm{g})$ and "Adam Chodun" (1.54 $\pm 0.04 \mu \mathrm{g} / \mathrm{g})($ Table 3$)$.

Table 3. Variability of the quantitative composition of flavonols and phloridzin in Rosa L. fruit samples

\begin{tabular}{|c|c|c|c|c|c|}
\hline Compound, $\mu \mathrm{g} / \mathrm{g}$ DW & Kaempferol-3-O-glucoside & Phloridzin & Quercetin & Quercitrin & Rutin \\
\hline R. canina & $3.34 \pm 0.51^{\mathrm{e}, \mathrm{f}}$ & $1.76 \pm 1.08^{\mathrm{c}, \mathrm{d}}$ & ND & $2.63 \pm 0.01^{\mathrm{e}}$ & ND \\
\hline R. multiflora & $10.14 \pm 0.71^{\mathrm{d}}$ & $20.78 \pm 1.12^{b}$ & $5.56 \pm 0.32^{c}$ & $142.58 \pm 2.94^{b}$ & $6.51 \pm 0.44^{c}$ \\
\hline R. multiflora "Nana" & $46.47 \pm 1.38^{a}$ & $28.75 \pm 1.25^{a}$ & $6.95 \pm 0.06^{b}$ & $278.47 \pm 2.65^{\mathrm{a}}$ & $19.44 \pm 1.41^{\mathrm{a}}$ \\
\hline R. pimpinellifolia "Papula" & ND & $3.99 \pm 0.27^{\mathrm{f}}$ & $6.73 \pm 0.32^{b, c}$ & $2.52 \pm 0.39^{\mathrm{e}}$ & ND \\
\hline R. pimpinellifolia "Single Cherry" & ND & ND & $43.96 \pm 0.12^{\mathrm{a}}$ & $1.83 \pm 0.04^{\mathrm{e}}$ & ND \\
\hline R. rugosa "Adam Chodun" & $12.47 \pm 0.52^{\mathrm{d}}$ & $13.26 \pm 0.75^{\mathrm{c}, \mathrm{d}}$ & ND & $1.75 \pm 0.04^{\mathrm{e}}$ & $1.54 \pm 0.04^{\mathrm{d}}$ \\
\hline R. rugosa "Dart's Defender" & $38.61 \pm 0.84^{b}$ & $14.96 \pm 0.94^{c}$ & ND & $32.09 \pm 1.03^{c}$ & $9.97 \pm 0.28^{c}$ \\
\hline R. rugosa "Fru Dagmar Hastrup" & $5.57 \pm 0.43^{\mathrm{e}}$ & $11.85 \pm 0.25^{\mathrm{c}, \mathrm{d}}$ & ND & $2.79 \pm 0.13^{\mathrm{e}}$ & ND \\
\hline R. rugosa "Kornik" & $12.52 \pm 0.56^{\mathrm{d}}$ & $5.73 \pm 0.21^{\mathrm{e}, \mathrm{f}}$ & ND & $3.83 \pm 0.12^{\mathrm{e}}$ & $0.87 \pm 0.11^{d}$ \\
\hline R. rugosa "Marie Bugnet" & $22.62 \pm 1.23^{c}$ & $9.55 \pm 0.48^{\mathrm{d}, \mathrm{e}}$ & ND & $21.88 \pm 0.70^{\mathrm{d}}$ & $14.03 \pm 0.46^{b}$ \\
\hline R. rugosa "Rudolf" & $0.68 \pm 0.01^{\mathrm{f}}$ & $1.51 \pm 0.01^{\mathrm{f}}$ & ND & $0.52 \pm 0.03^{\mathrm{e}}$ & ND \\
\hline
\end{tabular}

Different letters indicate statistically significant differences in the amounts of individual compounds of these groups in Rosa L. fruit samples $(p<0.05)$. ND-Not detected.

Hierarchical cluster analysis was performed for the samples of Rosa L. fruit, based on the content of dihydrochalcone phloridzin and the total content of flavan-3-ols, flavonols, and hydroxycinnamic acid. The investigated Rosa L. fruit samples have been grouped into two significant clusters (Figure 5). The first cluster consisted only of fruit samples of R. multiflora cultivar "Nana", while the second cluster included all the other investigated Rosa L. fruit samples. By the total content, flavan-3-ols were the prevailing group of the identified biologically active compounds, followed by, in descending order, flavonols, 
hydroxycinnamic acid, and phloridzin. Fruit samples of R. multiflora cultivar "Nana" differed from the others, as they had the highest total contents of flavan-3-ols, flavonols, phloridzin, and hydroxycinnamic acid.

\section{R. rugosa 'Marie Bugnet'}

R. canina

R. rugosa 'Adam Chodun'

R. rugosa 'Fru Dagmar Hastrup'

R. rugosa 'Dart's Defemeken'

R. pimpinellifolia 'Single Cherry

R. rugosa 'Rudolf'

R. rugosa 'Kornik'

R. pimpinellifolia 'Papula'

R. multiflora

R. multiflora 'Nana'
Rescaled Distance Cluster

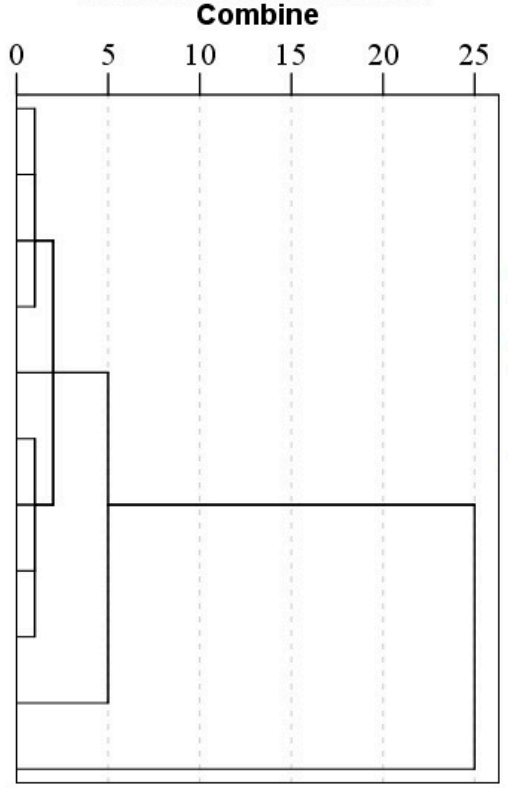

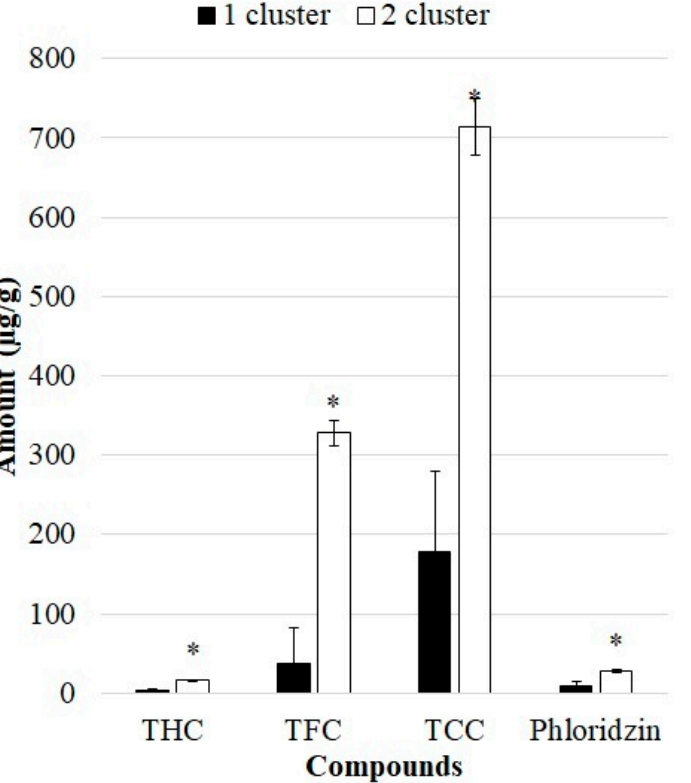

Figure 5. Dendrogram of the similarity of Rosa L. species, based on the composition of phenolic compounds in fruit samples. THC - total content of hydroxycinnamic acid; TCC - total content of flavan-3-ols; TFC—-total content of flavonols. * Indicates statistically significant differences in the amounts of phenolic compounds $(p<0.05)$.

A principal component analysis of the identified biologically active compounds in Rosa L. fruit samples was performed (Figure 6). Two principal components explaining $93.83 \%$ of the total data variance were used for the in-depth analysis. The first principal component (PC I), which describes $56.08 \%$ of the total data variance, had a very strong positive correlation with the content of phloridzin $(0.974)$ and a strong positive correlation with the total content of the other flavonoids (flavonols (0.806) and flavan-3-ols (0.769)). The second principal component (PC II), which describes $37.75 \%$ of the total data variance, had a very strong positive correlation with the total content of hydroxycinnamic acid (0.965). The clustering of the samples along PC I can be explained by the highest values of the total contents of flavonoids. Fruit samples of R. multiflora cultivars "Nana" and R. multiflora were distanced from all the others and were grouped at the positive side of the I PC as the total contents of flavonoids were high in these fruit samples. PC II differentiated these fruit samples by the total content of hydroxycinnamic acid. The highest total content of hydroxycinnamic acid scoring high in PC II was detected in the fruit samples of R. multiflora cultivar "Nana". The other fruit samples were arranged into two distinct groups. Fruit samples of R. pimpinellifolia cultivar "Papula", R. pimpinellifolia cultivar "Single Cherry", R. rugosa cultivar "Kornik", and R. rugosa cultivar "Rudolf" were scattering along negative PC I and positive PC II. In these fruit samples, the total contents of flavonoids were lower than the mean. Meanwhile, we determined that the total content of hydroxycinnamic acid in these fruit samples was higher than the mean. Fruit samples of $R$. canina and R. rugosa cultivars "Adam Chodun", "Dart's Defender", "Fru Dagmar Hastrup", and "Marie Bugnet" were located near the zero point of PC I. The content of phloridzin was higher than the mean. On the other hand, the total contents of flavonols and flavan-3-ols with high positive loadings in PC I were lower than the mean values. Moreover, fruit samples of these five species showed negative score values of PC II. The total content of hydroxycinnamic acid was determined in the range of the lowest to the mean values in these fruit samples. 

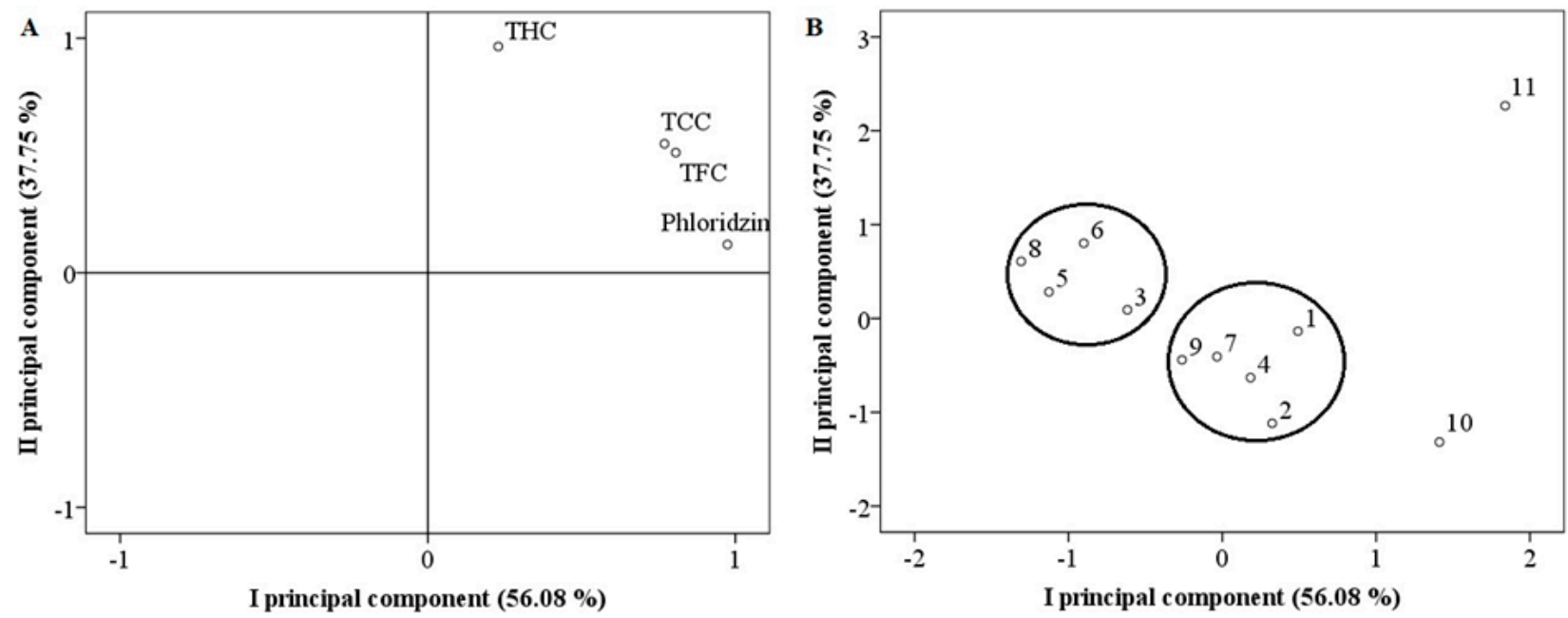

Figure 6. Principal component analysis: loading (A) and score (B) plots of fruit samples of different Rosa L. species. THCtotal content of hydroxycinnamic acid; TCC—-total content of flavan-3-ols; TFC—-total content of flavonols. 1-R. rugosa cultivar "Dart's Defender"; 2-R. rugosa cultivar "Adam Chodun"; 3-R. rugosa cultivar "Kornik"; 4-R. rugosa cultivar "Marie Bugnet"; 5—R. pimpinellifolia cultivar "Single Cherry"; 6-R. pimpinellifolia cultivar "Papula"; 7—R. canina; 8—R. rugosa cultivar "Rudolf"; 9-R. rugosa cultivar "Fru Dagmar Hastrup"; 10-R. multiflora; 11-R. multiflora cultivar "Nana".

As a consequence, R. multiflora cultivar "Nana" fruit samples formed a separate group indicating a different profile of phenolic compounds from other Rosa L. species. Meanwhile, our research revealed similarities between the other investigated fruit samples of Rosa L. species in the composition of phenolic compounds.

\subsection{Determination of the Antioxidant Activity of Rosa L. Fruit-Sample Extracts In Vitro}

The effectiveness of raw medicinal plant materials and preparations whose pharmacological activity is determined by phenolic compounds has been confirmed by abundant research data [61-63]. The use of raw medicinal plant materials for food and the use of phenolic compound-containing botanical preparations have been determined to have an association with the incidence of malignancies and cardiovascular and neurodegenerative diseases [64,65]. Epidemiological studies have demonstrated the ability of antioxidants to reduce or completely stop the progression of many chronic illnesses [66,67]. Studies on the antioxidant activity of phenolic compounds and their application for disease prevention have been carried out $[68,69]$. When conducting prospective studies on antioxidant activity, it is expedient to conduct an in vitro evaluation of the radical scavenging and reducing activity of the fruit-sample extracts of Rosa L. grown in Lithuanian collections. The results obtained during the study will be useful for the selection of Rosa L. cultivars in order to provide consumers with antioxidant-rich products, will help in the assessment and standardization of the quality of raw medicinal plant materials and their products, and will allow for predicting the antioxidant effect of Rosa L. fruit extracts in vivo.

Fruit-sample extracts of different species and cultivars of Rosa L. were analyzed, using an in vitro DPPH radical scavenging activity assay, and the variability of radical scavenging activity was determined to range between $188.39 \pm 9.61 \mu \mathrm{mol} \mathrm{TE} / \mathrm{g}$ and $397.2 \pm 16.59 \mu \mathrm{mol} \mathrm{TE} / \mathrm{g}$ (Figure 7). The mean radical scavenging activity of Rosa L. fruit samples in vitro was $265.68 \pm 11.8 \mu \mathrm{mol} \mathrm{TE} / \mathrm{g}$. Extracts of fruit samples of $R$. pimpinellifolia cultivar "Single Cherry" and R. rugosa cultivar "Adam Chodun" demonstrated the strongest radical scavenging activity (respectively, $397.2 \pm 16.59 \mu \mathrm{mol} \mathrm{TE} / \mathrm{g}$ and $335.53 \pm 11.13 \mu \mathrm{mol} \mathrm{TE} / \mathrm{g})$. 


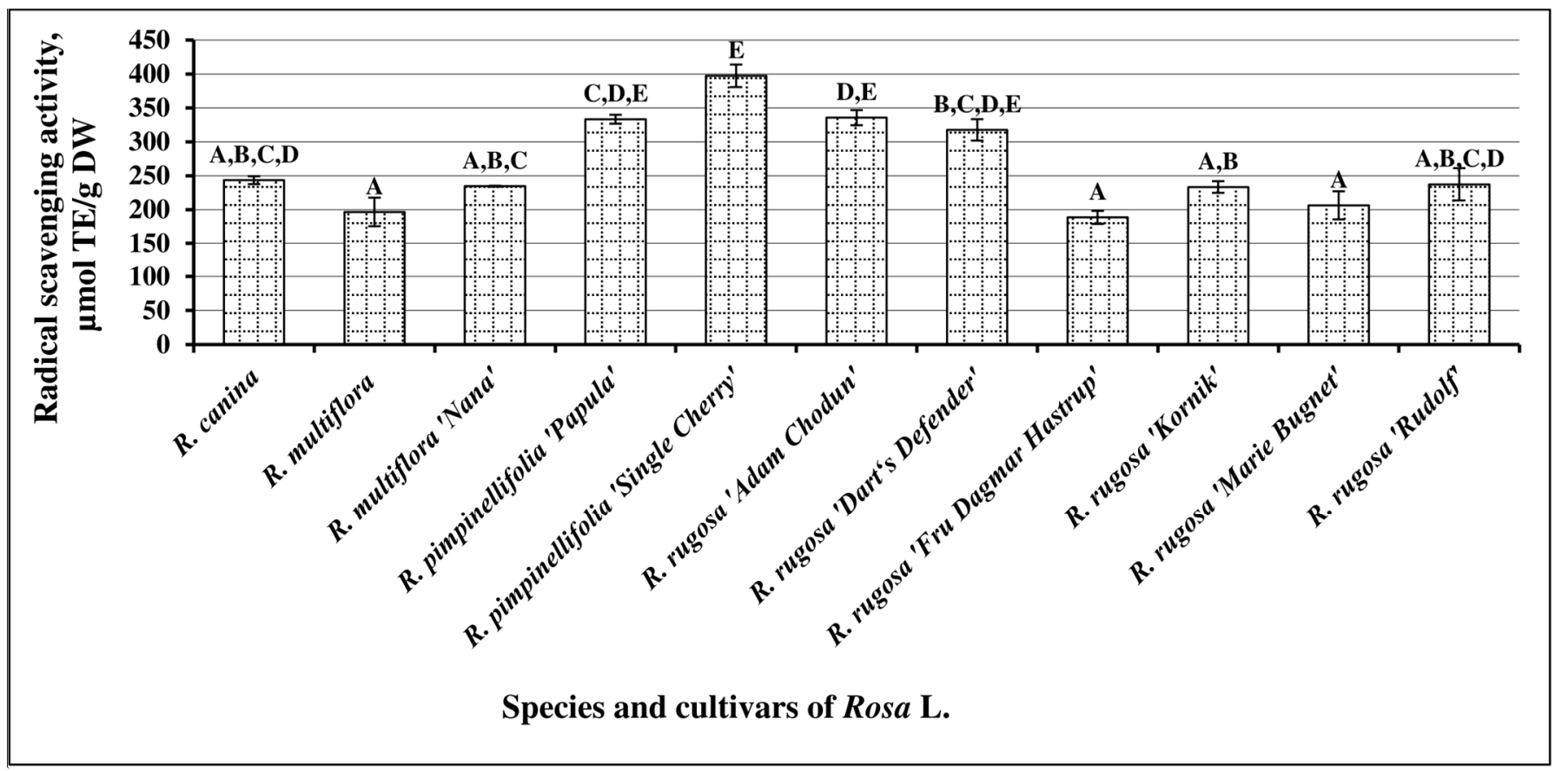

Figure 7. Variability of the radical scavenging activity of Rosa L. fruit-sample extracts in vitro; different letters indicate statistically significant $(p<0.05)$ differences between the samples.

The evaluation of the reducing activity of Rosa L. fruit-sample extracts, using the in vitro FRAP assay, showed that the reducing activity ranged from $41.47 \pm 2.3 \mu \mathrm{mol}$ $\mathrm{TE} / \mathrm{g}$ to $263.15 \pm 9.83 \mu \mathrm{mol} \mathrm{TE} / \mathrm{g}$ (Figure 8 ). The mean reducing activity in vitro was $137.81 \pm 13.92 \mu \mathrm{mol} \mathrm{TE} / \mathrm{g}$. The strongest reducing activity was determined in the extracts of fruit samples of $R$. pimpinellifolia cultivar "Single Cherry" (263.15 $\pm 9.83 \mu \mathrm{mol} \mathrm{TE} / \mathrm{g})$ and R. rugosa cultivar "Adam Chodun" (229.56 $\pm 4.74 \mu \mathrm{mol} \mathrm{TE} / \mathrm{g})$.

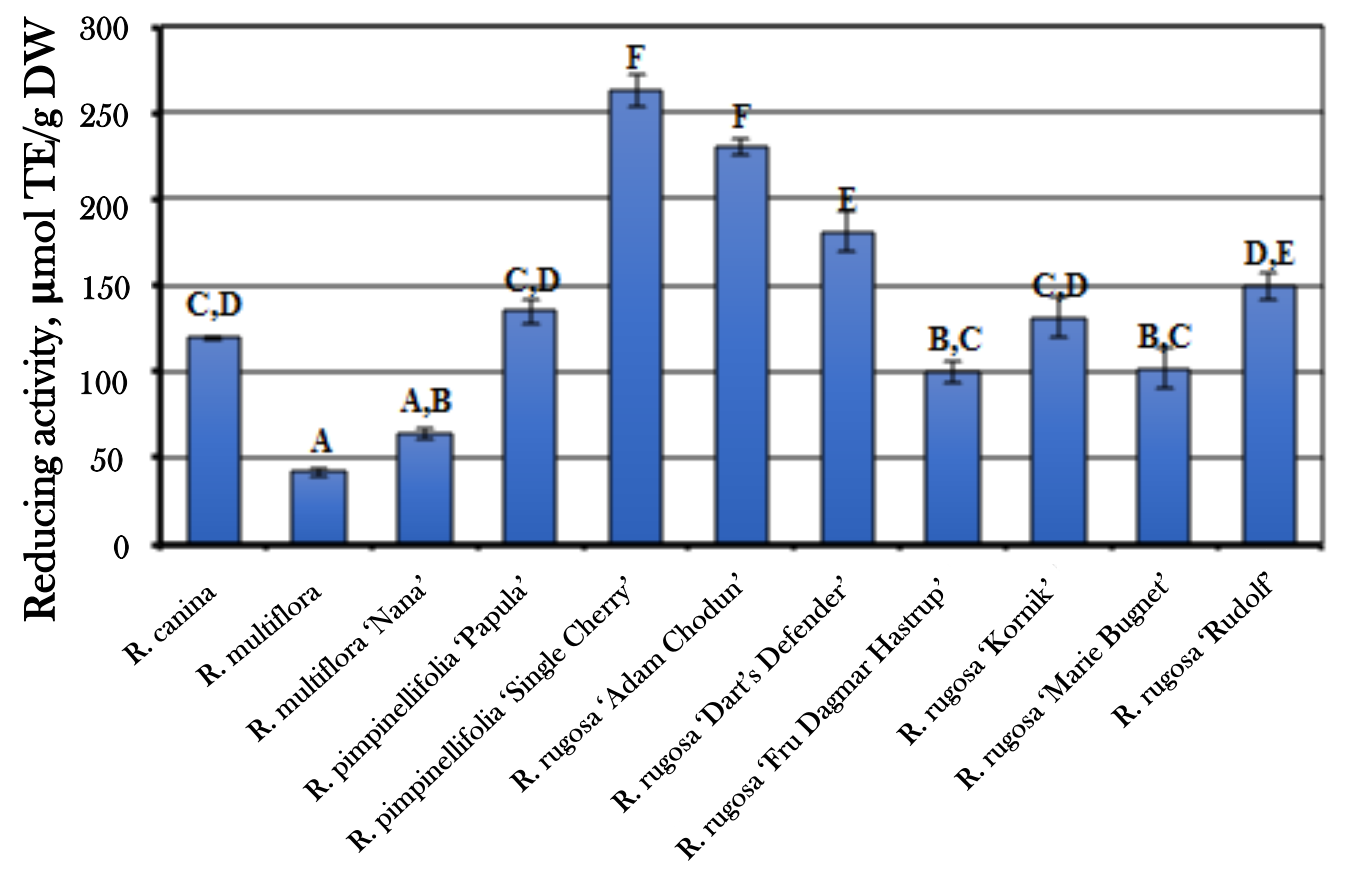

Species and cultivars of Rosa L.

Figure 8. Variability of the reducing activity of Rosa L. fruit-sample extracts in vitro; different letters indicate statistically significant $(p<0.05)$ differences between the samples. 
There was a strong correlation between the total amount of phenolic compounds determined in fruit-sample extracts of different Rosa L. species and the radical scavenging and reducing activity of their extracts in vitro $(R=0.767$ and 0.727 , respectively, $p<0.05)$.

Polish researchers determined the in vitro antioxidant activity of fruit-sample extracts of plants of the genus Rosa L. by applying DPPH and FRAP assays (11.01 $\pm 0.74 \mathrm{mmol}$ $\mathrm{TE} / 100 \mathrm{~g}$ and $18.33 \pm 0.71 \mathrm{mmol} \mathrm{TE} / 100 \mathrm{~g}$, respectively) [19]. In our study, extracts of Rosa L. fruit samples showed stronger radical scavenging activity in vitro, and their reducing activity was close to or even slightly higher than that determined by the aforementioned researchers. Tahirović et al. and Taneva et al., studied the reducing activity of Rosa L. fruit-sample extracts in vitro by applying the FRAP assay and obtained higher values than those we obtained in our study [35,70].

\section{Conclusions}

Scientific articles present research data on the qualitative and quantitative composition of biologically active compounds in Rosa L. fruit. Phenolic compounds determined in Rosa L. fruit have a wide range of biological effects and determine the use of Rosa L. fruit preparations in medical practice. To expand the provision of the raw material of Rosa L. fruit and to prepare high-quality raw medicinal plant materials, it is expedient to perform studies on the qualitative and quantitative composition of phenolic compounds in fruit of different cultivars of $R$. rugosa ("Rudolf", "Dart's Defender", "Marie Bugnet", "Fru Dagmar Hastrup", "Kornik", and "Adam Chodun"), R. multiflora ("Nana"), and R. pimpinellifolia ("Papula" and "Single Cherry") grown in Lithuanian collections. In this study, we determined the overall variability of the quantitative composition of phenolic compounds, hydroxycinnamic acid derivatives, and flavonoids in Rosa L. fruit samples and evaluated the antioxidant activity of their extracts in vitro. The obtained results will allow for the selection of plant cultivars that accumulate the highest amounts of biologically active compounds and for the preparation of high-quality raw medicinal plant materials.

Rosa L. fruits are valuable raw medicinal plant materials that accumulate biologically active compounds - phenolic acids and flavonoids. Based on the obtained research data, we would recommend using fruit of R. pimpinellifolia cultivar "Single Cherry" and R. rugosa cultivar "Adam Chodun" for the production of various medicinal products. Extracts from the samples of the fruit of these Rosa L. species and cultivars showed the strongest antioxidant activity in vitro.

Hierarchical cluster analysis and principal component analysis revealed that R. multiflora "Nana" fruit samples had a different quantitative composition of phenolic compounds from the other species of the Rosa genus. Fruit samples of R. multiflora cultivar "Nana" had an exclusive phytochemical composition, as these fruit samples were determined to contain high amounts of all the identified phenolic compounds. This cultivar could be selected as a desirable raw material for the preparation of Rosa L. fruit products.

Recently, the raw material of the Rosa L. fruit has been used in the production of food, probiotic beverages, yogurts, and natural food additives. Biologically active compounds of Rosa L. fruit not only improve the quality but also have health-promoting and diseasepreventive effects. The relationship between food and health is becoming increasingly important, as consumers want to eat healthy, tasty, and natural food grown in an organic environment. For this reason, it is important to investigate new Rosa L. species and cultivars, which could be a potential source of herbal raw material. Phenolic compounds are natural antioxidants having an impact on a prevention of various diseases. Our investigated fruit samples of Rosa L. species and cultivars could be characterized as having a broad variety of qualitative and quantitative composition of phenolic compounds. New knowledge about phytochemical composition, antioxidant activity and possibility to use Rosa L. herbal raw material in the production of functional food or as a perspective herbal raw material in practical medicine was obtained. 
Author Contributions: Conceptualization, M.L. and V.J.; methodology, M.L. and K.Z.; formal analysis, R.J. and V.Ž.; investigation, R.J. and V.Ž.; resources, I.N.; data curation, M.L. and V.J.; writingoriginal draft preparation, M.L. and V.J.; writing-review and editing, M.L. and V.J.; visualization, K.Z.; supervision, V.J. All authors have read and agreed to the published version of the manuscript.

Funding: This research received no external funding.

Institutional Review Board Statement: Not applicable.

Informed Consent Statement: Not applicable.

Data Availability Statement: All datasets generated for this study are included in the article.

Conflicts of Interest: The authors declare no conflict of interest.

\section{References}

1. Hummer, K.E.; Janick, J. Rosaceae: Taxonomy, economic importance, genomics. In Genetics and genomics of Rosaceae; Folta, K.M., Gardiner, S.E., Eds.; Springer: New York, NY, USA, 2009; pp. 1-17.

2. Nybom, H.; Carlson-Nilsson, U.; Werlemark, G.; Uggla, M. Different levels of morphometric variation in three heterogamous dogrose species (Rosa sect. Caninae, Rosaceae). Plant Syst. Evol. 1997, 204, 207-224. [CrossRef]

3. Czyzowska, A.; Klewicka, E.; Pogorzelski, E.; Nowak, A. Polyphenols, vitamin C and antioxidant activity in wines from Rosa canina L. and Rosa rugosa Thunb. J. Food Compos. Anal. 2015, 39, 62-68. [CrossRef]

4. Ghazghazi, H.; Miguel, M.G.; Hasnaoui, B.; Sebei, H.; Ksontini, M.; Figueiredo, A.C.; Barroso, J.G. Phenols, Essential Oils and Carotenoids of Rosa canina from Tunisia and Their Antioxidant Activities. Afr. J. Biotechnol. 2010, 9, $2709-2716$.

5. Council of Europe. Dog rose, 07/2019:1510. In European Pharmacopoeia, 10th ed.; Council of Europe: Strasbourg, France, 2019; pp. 1415-1416.

6. Jiménez, S.; Jiménez-Moreno, N.; Luquin, A.; Laguna, M.; Rodríguez-Yoldi, M.J.; Ancín-Azpilicueta, C. Chemical composition of rosehips from different Rosa species: An alternative source of antioxidants for the food industry. Food Addit. Contam. Part A 2017, 34, 1121-1130. [CrossRef]

7. Nađpal, J.D.; Lesjak, M.M.; Šibul, F.S.; Anačkov, G.T.; Četojević-Simin, D.D.; Mimica-Dukić, N.M.; Beara, I.N. Comparative study of biological activities and phytochemical composition of two rose hips and their preserves: Rosa canina L. and Rosa arvensis Huds. Food Chem. 2016, 192, 907-914. [CrossRef] [PubMed]

8. Barros, L.; Carvalho, A.M.; Morais, J.S.; Ferreira, I.C.F.R. Strawberry-tree, blackthorn and rose fruits: Detailed characterisation in nutrients and phytochemicals with antioxidant properties. Food Chem. 2010, 120, 247-254. [CrossRef]

9. Orhan, D.D.; Hartevioğlu, A.; Küpeli, E.; Yesilada, E. In vivo Anti-Inflammatory and antinociceptive activity of the crude extract and fractions from Rosa canina L. fruits. J. Ethnopharmacol. 2007, 112, 394-400. [CrossRef] [PubMed]

10. Wenzig, E.M.; Widowitz, U.; Kunert, O.; Chrubasik, S.; Bucar, F.; Knauder, E.; Bauer, R. Phytochemical composition and in vitro pharmacological activity of two rose hip (Rosa canina L.) preparations. Phytomedicine 2008, 15, 826-835. [CrossRef]

11. Barros, L.; Carvalho, A.M.; Ferreira, I.C.F.R. Exotic fruits as a source of important phytochemicals: Improving the traditional use of Rosa canina fruits in Portugal. Food Res. Int. 2011, 44, 2233-2236. [CrossRef]

12. Tumbas, V.T.; Čanadanović-Brunet, J.M.; Četojević-Simin, D.D.; Ćetković, G.S.; Đilas, S.M.; Gille, L. Effect of rosehip (Rosa canina L.) phytochemicals on stable free radicals and human cancer cells. J. Sci. Food Agric. 2012, 92, 1273-1281. [CrossRef]

13. Willich, S.N.; Rossnagel, K.; Roll, S.; Wagner, A.; Mune, O.; Erlendson, J.; Kharazmi, A.; Sörensen, H.; Winther, K. Rose hip herbal remedy in patients with rheumatoid arthritis-A randomised controlled trial. Phytomedicine 2010, 17, 87-93. [CrossRef]

14. Saaby, L.; Jäger, A.K.; Moesby, L.; Hansen, E.W.; Christensen, S.B. Isolation of immunomodulatory triterpene acids from a standardized rose hip powder (Rosa canina L.). Phytother. Res. 2011, 25, 195-201. [CrossRef]

15. Ashtiyani, S.C.; Najafi, H.; Jalalvandi, S.; Hosseinei, F. Protective effects of Rosa canina L fruit extracts on renal disturbances induced by reperfusion injury in rats. Iran. J. Kidney Dis. 2013, 7, 290.

16. Vossen, E.; Utrera, M.; De Smet, S.; Morcuende, D.; Estévez, M. Dog rose (Rosa canina L.) as a functional ingredient in porcine frankfurters without added sodium ascorbate and sodium nitrite. Meat Sci. 2012, 92, 451-457. [CrossRef]

17. Koczka, N.; Stefanovits-Bányai, É.; Ombódi, A. Total polyphenol content and antioxidant capacity of rosehips of some Rosa species. Medicines 2018, 5, 84. [CrossRef] [PubMed]

18. Demir, N.; Yildiz, O.; Alpaslan, M.; Hayaloglu, A.A. Evaluation of volatiles, phenolic compounds and antioxidant activities of rose hip (Rosa L.) fruits in Turkey. LWT Food Sci. Technol. 2014, 57, 126-133. [CrossRef]

19. Szołtysik, M.; Kucharska, A.Z.; Sokół-Łętowska, A.; Dabrowska, A.; Bobak, Ł.; Chrzanowska, J. The effect of Rosa spinosissima fruits extract on lactic acid bacteria growth and other yoghurt parameters. Foods 2020, 9, 1167. [CrossRef] [PubMed]

20. Naik, S.R.; Thakare, V.N.; Joshi, F.P. Functional foods and herbs as potential immunoadjuvants and medicines in maintaining healthy immune system: A commentary. J. Complement. Integr. Med. 2010, 7, 1-29. [CrossRef]

21. Asgary, S.; Rastqar, A.; Keshvari, M. Functional food and cardiovascular disease prevention and treatment: A review. J. Am. Coll. Nutr. 2018, 37, 429-455. [CrossRef] 
22. Langhans, W. Food components in health promotion and disease prevention. J. Agric. Food Chem. 2018, 66, 2287-2294. [CrossRef] [PubMed]

23. Stalikas, C.D. Extraction, separation, and detection methods for phenolic acids and flavonoids. J. Sep. Sci. 2007, 30, 3268-3295. [CrossRef] [PubMed]

24. Naczk, M.; Shahidi, F. Extraction and analysis of phenolics in food. J. Chromatogr. A 2004, 1054, 95-111. [CrossRef]

25. Tsao, R.; Deng, Z. Separation procedures for naturally occurring antioxidant phytochemicals. J. Chromatogr. B 2004, 812, 85-99. [CrossRef]

26. Council of Europe. Loss on drying, 07/2019:20232. In European Pharmacopoeia, 10th ed.; Council of Europe: Strasbourg, France, 2019; p. 57.

27. Bobinaite, R.; Viškelis, P.; Venskutonis, P.R. Variation of total phenolics, anthocyanins, ellagic acid and radical scavenging capacity in various raspberry (Rubus spp.) cultivars. Food Chem. 2012, 132, 1495-1501. [CrossRef]

28. Urbonavičiūtè, A.; Jakštas, V.; Kornyšova, O.; Janulis, V.; Maruška, A. Capillary electrophoretic analysis of flavonoids in single-styled hawthorn (Crataegus monogyna Jacq.) Ethanolic Extracts. J. Chromatogr. A 2006, 1112, 339-344. [CrossRef]

29. Fraisse, D.; Felgines, C.; Texier, O.; Lamaison, J.-L. Caffeoyl derivatives: Major antioxidant compounds of some wild herbs of the Asteraceae family. Food Nutr. Sci. 2011, 2, 181-192. [CrossRef]

30. Brand-Williams, W.; Cuvelier, M.E.; Berset, C. Use of a free radical method to evaluate antioxidant activity. LWT Food Sci. Technol. 1995, 28, 25-30. [CrossRef]

31. Benzie, I.F.F.; Strain, J.J. The ferric reducing ability of plasma (FRAP) as a measure of "antioxidant Power": The FRAP Assay. Anal. Biochem. 1996, 239, 70-76. [CrossRef]

32. González-Burgos, E.; Liaudanskas, M.; Viškelis, J.; Žvikas, V.; Janulis, V.; Gómez-Serranillos, M.P. Antioxidant activity, neuroprotective properties and bioactive constituents analysis of varying polarity extracts from Eucalyptus globulus leaves. J. Food Drug Anal. 2018, 26, 1293-1302. [CrossRef] [PubMed]

33. Yang, Q.-Q.; Zhang, D.; Farha, A.K.; Yang, X.; Li, H.-B.; Kong, K.-W.; Zhang, J.-R.; Chan, C.-L.; Lu, W.-Y.; Corke, H.; et al. Phytochemicals, essential oils, and bioactivities of an underutilized wild fruit cili (Rosa roxburghii). Ind. Crop. Prod. 2020, 143, 111928. [CrossRef]

34. Nađpal, J.D. Phytochemical composition and in vitro functional properties of three wild rose hips and their traditional preserves. Food Chem. 2018, 241, 290-300. [CrossRef] [PubMed]

35. Tahirović, A.; Bašić, N. Determination of phenolic content and antioxidant activity of Rosa canina L. fruits in different extraction systems. Work. Fac. For. Univ. Sarajevo 2017, 47, 13.

36. Heleno, S.A.; Martins, A.; Queiroz, M.J.R.P.; Ferreira, I.C.F.R. Bioactivity of phenolic acids: Metabolites versus parent compounds: A review. Food Chem. 2015, 173, 501-513. [CrossRef] [PubMed]

37. Ghasemzadeh, A.; Ghasemzadeh, N. Flavonoids and phenolic acids: Role and biochemical activity in plants and human. J. Med. Plants Res. 2011, 5, 6697-6703. [CrossRef]

38. Kumar, N.; Goel, N. Phenolic acids: Natural versatile molecules with promising therapeutic applications. Biotechnol. Rep. 2019, 24, e00370. [CrossRef]

39. Taofiq, O.; Calhelha, R.C.; Heleno, S.; Barros, L.; Martins, A.; Santos-Buelga, C.; Queiroz, M.J.R.P.; Ferreira, I.C.F.R. The contribution of phenolic acids to the anti-inflammatory activity of mushrooms: Screening in phenolic extracts, individual parent molecules and synthesized glucuronated and methylated derivatives. Food Res. Int. 2015, 76, 821-827. [CrossRef]

40. Buys-Gonçalves, G.F.; Abreu, L.A.S.; Gregorio, B.M.; Sampaio, F.J.B.; Pereira-Sampaio, M.A.; de Souza, D.B. Antioxidants as renoprotective agents for ischemia during partial nephrectomy. BioMed Res. Int. 2019, 2019, 1-12. [CrossRef]

41. Domitrović, R.; Cvijanović, O.; Šušnić, V.; Katalinić, N. Renoprotective mechanisms of chlorogenic acid in cisplatin-induced kidney injury. Toxicology 2014, 324, 98-107. [CrossRef]

42. Saha, P.; Talukdar, A.D.; Nath, R.; Sarker, S.D.; Nahar, L.; Sahu, J.; Choudhury, M.D. Role of natural phenolics in hepatoprotection: A mechanistic review and analysis of regulatory network of associated genes. Front. Pharmacol. 2019, 10, 509. [CrossRef]

43. Vinayagam, R.; Jayachandran, M.; Xu, B. Antidiabetic effects of simple phenolic acids: A comprehensive review: Antidiabetic effects of phenolic acids. Phytother. Res. 2016, 30, 184-199. [CrossRef]

44. Aron, P.M.; Kennedy, J.A. Flavan-3-Ols: Nature, occurrence and biological activity. Mol. Nutr. Food Res. 2008, 52, 79-104. [CrossRef]

45. Braicu, C.; Pilecki, V.; Balacescu, O.; Irimie, A.; Berindan Neagoe, I. The relationships between biological activities and structure of flavan-3-ols. Int. J. Mol. Sci. 2011, 12, 9342-9353. [CrossRef] [PubMed]

46. Lei, L.; Yang, Y.; He, H.; Chen, E.; Du, L.; Dong, J.; Yang, J. Flavan-3-ols consumption and cancer risk: A meta-analysis of epidemiologic studies. Oncotarget 2016, 7, 73573-73592. [CrossRef] [PubMed]

47. Mena, P.; Domínguez-Perles, R.; Gironés-Vilaplana, A.; Baenas, N.; García-Viguera, C.; Villaño, D. Flavan-3-ols, anthocyanins, and inflammation: Anti-inflammatory effects of anthocyanins and flavan-3-ols. IUBMB Life 2014, 66, 745-758. [CrossRef] [PubMed]

48. Hackman, R.M.; Polagruto, J.A.; Zhu, Q.Y.; Sun, B.; Fujii, H.; Keen, C.L. Flavanols: Digestion, absorption and bioactivity. Phytochem. Rev. 2007, 7, 195-208. [CrossRef]

49. Raman, G.; Shams-White, M.; Avendano, E.E.; Chen, F.; Novotny, J.A.; Cassidy, A. Dietary intakes of flavan-3-ols and cardiovascular health: A field synopsis using evidence mapping of randomized trials and prospective cohort studies. Syst. Rev. 2018, 7, 1-11. [CrossRef] 
50. Mulero, J.; Abellán, J.; Zafrilla, P.; Amores, D.; Hernández Sánchez, P. Sustancias bioactivas con efecto preventivo en la enfermedad cardiovascular. Nutr. Hosp. 2015, 32, 1462-1467.

51. Tabaszewska, M.; Najgebauer-Lejko, D. The content of selected phytochemicals and in vitro antioxidant properties of rose hip (Rosa canina L.) tinctures. NFS J. 2020, 21, 50-56. [CrossRef]

52. Fetni, S.; Bertella, N.; Ouahab, A.; Martinez Zapater, J.M.; De Pascual-Teresa Fernandez, S. Composition and biological activity of the Algerian plant Rosa canina L. by HPLC-UV-MS. Arab. J. Chem. 2020, 13, 1105-1119. [CrossRef]

53. Cho, Y.-J. Antioxidant and antimicrobial activity of Rosa multiflora Thunberg fruits extracts. Curr. Res. Agric. Life Sci. 2013, 31, 170-176.

54. Sharma, A.; Sharma, P.; Tuli, H.S.; Sharma, A.K. Phytochemical and pharmacological properties of flavonols. eLS 2018, 1-12.

55. Nasri, I.; Chawech, R.; Girardi, C.; Mas, E.; Ferrand, A.; Vergnolle, N.; Fabre, N.; Mezghani-Jarraya, R.; Racaud-Sultan, C. Anti-inflammatory and anticancer effects of flavonol glycosides from Diplotaxis harra through GSK3 $\beta$ regulation in intestinal cells. Pharm. Biol. 2017, 55, 124-131. [CrossRef] [PubMed]

56. Maalik, A.; Khan, F.; Mumtaz, A.; Mehmood, A.; Azhar, S.; Atif, M.; Karim, S.; Altaf, Y.; Tariq, I. Pharmacological applications of quercetin and its derivatives: A short review. Trop. J. Pharm Res 2014, 13, 1561-1566. [CrossRef]

57. Lakhanpal, P.; Rai, D.K. Role of Quercetin in Cardiovascular Diseases. Int. J. Med. Updat. 2008, 3, 31-49. [CrossRef]

58. Ferenczyova, K.; Kalocayova, B.; Bartekova, M. Potential implications of quercetin and its derivatives in cardioprotection. Int. J. Mol. Sci. 2020, 21, 1585. [CrossRef]

59. Khan, H.; Ullah, H.; Aschner, M.; Cheang, W.S.; Akkol, E.K. Neuroprotective effects of quercetin in Alzheimer's disease. Biomolecules 2019, 10, 59. [CrossRef] [PubMed]

60. Magalingam, K.B.; Radhakrishnan, A.; Haleagrahara, N. Protective effects of quercetin glycosides, rutin, and isoquercetrin against 6-hydroxydopamine (6-OHDA)-induced neurotoxicity in rat pheochromocytoma (PC-12) cells. Int. J. Immunopathol. Pharmacol. 2016, 29, 30-39. [CrossRef]

61. Cai, Y.; Luo, Q.; Sun, M.; Corke, H. Antioxidant activity and phenolic compounds of 112 traditional chinese medicinal plants associated with anticancer. Life Sci. 2004, 74, 2157-2184. [CrossRef]

62. Dai, J.; Mumper, R.J. Plant phenolics: Extraction, analysis and their antioxidant and anticancer properties. Molecules 2010, 15, 7313-7352. [CrossRef]

63. Heim, K.E.; Tagliaferro, A.R.; Bobilya, D.J. Flavonoid antioxidants: Chemistry, metabolism and structure-activity relationships. J. Nutr. Biochem. 2002, 13, 572-584. [CrossRef]

64. Pandey, K.B.; Rizvi, S.I. Plant polyphenols as dietary antioxidants in human health and disease. Oxid. Med. Cell. Longev. 2009, 2, 270-278. [CrossRef]

65. Scalbert, A.; Johnson, I.T.; Saltmarsh, M. Polyphenols: Antioxidants and beyond. Am. J. Clin. Nutr. 2005, 81, 215S-217S. [CrossRef] [PubMed]

66. Hajhashemi, V.; Vaseghi, G.; Pourfarzam, M.; Abdollahi, A. Are antioxidants helpful for disease prevention? Res. Pharm. Sci. 2010, 5, 1-8. [PubMed]

67. García-Sánchez, A.; Miranda-Díaz, A.G.; Cardona-Muñoz, E.G. The role of oxidative stress in physiopathology and pharmacological treatment with pro- and antioxidant properties in chronic diseases. Oxid. Med. Cell. Longev. 2020, $2020,2082145$. [CrossRef]

68. Szymanska, R.; Pospíšil, P.; Kruk, J. Plant-derived antioxidants in disease prevention 2018. Oxid. Med. Cell. Longev. 2018, 2018, 1-2. [CrossRef] [PubMed]

69. Serafini, M. The role of antioxidants in disease prevention. Medicine 2006, 34, 533-535. [CrossRef]

70. Taneva, I.; Petkova, N.; Dimov, I.; Ivanov, I.; Denev, P. Characterization of rose hip (Rosa canina L.) fruits extracts and evaluation of their in vitro antioxidant activity. J. Pharmacogn. Phytochem. 2016, 5, 35-38. 